\title{
Cost and Income Analysis of Tomato cultivation in Ghazipur District of Uttar Pradesh, India
}

\author{
Punam Kushwaha, Harendra Pratap Singh Chaudhri*, R.R. Verma and R.R. Kushwaha
}

Department of Agricultural Economics, NDUAT kumarganj Faizabad (U.P.), India

*Corresponding author

\begin{abstract}
A B S T R A C T
Keywords

Cost, Income,

Return, Outputinput ratio

Article Info

Accepted:

10 June 2018

Available Online:

10 July 2018

Study on cost and income analysis was conducted in Bhanwarkola block of Ghazipur district of eastern Uttar Pradesh. A sample of 50 respondent was chosen through purposive cum random sampling technique were categorised as marginal ( $<1 \mathrm{ha})$, small (1-2 ha) and medium (2-4 ha) size of farms. A survey was conducted by personal interview method with pre structure schedule. Simple tabular analysis was done to find out the result. It was found that tomato cultivation was profitable at all categories of farm. The costs of cultivation were highest on medium farms Rs.41318.40, followed by small farms Rs.39843.88 and marginal farms Rs. 38978.50 respectively. The overall average costs of cultivation were observed Rs. 39481.95 on sample farms. Gross income highest on medium farms Rs. 78400.00, followed by small farms Rs. 78715.00 and marginal farms Rs. 79440.00 per hectare and the overall average gross income was observed Rs. 79126.70. It shows the cost of cultivation and gross income was positively related with size of sample farms, whereas, negative trend of net income with farm size. Output - Input cost $\mathrm{C}_{3}$ ratio were 1:2.03,1:1.98, 1:1.90 on marginal, small and medium size group of farm respectively which was overall recorded as 1:2.00.
\end{abstract}

\section{Introduction}

Tomato is one of the most important vegetables crops of the world with $3^{\text {rd }}$ ranking in area and production. Tomato is one of the most popular vegetable of great commercial and nutritional value. Tomato is grown and consumed by the people, around the world. It is a warm season crop. It is also grown as an off season vegetable in hilly area of India and farmers earn enough income by supplying their produce in the plains from June to September.
In our country, huge quantities of tomato are utilized to produce, soup, juice, ketchup, puree, paste and powder. It contents 94 per cent moisture, 0.9 per cent protein, 0.2 per cent fat, 0.8 per cent fibre, 3.4 per cent carbohydrates and rich source of vitamin $\mathrm{c}$. Presence of vitamin c, variety of colour and flavors in tomato, makes it popular vegetable among the public. Due to good keeping quality tomato can be preserved and available in the market round the year (A Handbook of Vegetable science). 
Tomato fruits mature at green stage could be stored successfully at $10-12^{0} \mathrm{C}$ in polyethylene bags of 100 gauge thickness for 4-5 weeks storage life of tomato could be increased by keeping in evaporative cool storage (zero energy cool chamber). The cool chamber has been found effective in maintaining fruit acceptability for longer period and minimum weight loss considerably.

Higher yield is of no importance if the farmer does not get the remunerative price for his produce. Thus the marketing assumes significant importance to the farmer for getting higher income from the vegetable cultivation. If a grower wants to make profitable production, he must produce good quality of vegetable to acquire the specified market needs.

Thus the grower's decision to cultivate various varieties of vegetables would largely depend upon the demand and preferences of the consumer's prevailing in the market. Some time vegetable producer are in the lack of contact with the market channel and consequently do not get the fair price of their produce which they obtain after putting a lot of labour and capital. The study of marketing cost and margins is useful both for the producer (seller) and consumer. A reference to the marketing costs and margins would show whether the service of the intermediaries are provided at reasonable cost or not. Moreover, the study of the marketing margins can be used to fix market functionaries and judge the efficiency of marketing system. There is great variation in prices from lean period to peak period affecting marketing costs and margins and producer's share in consumer's rupees and ultimately affecting the farmer's income. Thus the farmers, especially marginal and small can increase their income and employment from production of tomato.

Seeing the importance of the crop, it seems necessary to study the economics of tomato cultivation in order to find the costs involved in its cultivation and profit received from a hectare, the result of the study can guide the framers to allocate the opportunity area of this crop in his crop production plan the study on costs and income analysis was conducted in Block Bhawanrkola of district Ghazipur eastern Uttar Pradesh with following objectives:

1. To study the different type of costs involve in tomato cultivation.

2. To study the various income measure received from tomato cultivation.

\section{Materials and Methods}

Methodological aspect of study on "Economic analysis of tomato in Ghazipur district of eastern Uttar Pradesh" has been discussed under the following four heads:

1. Sampling technique.

2. Collection of data and method of enquiry.

3. Period of enquiry.

4. Analytical tools

\section{Sampling technique}

Multistage stratified purposive cum random sampling technique was used for the selection of district, block, villages and respondents (tomato grower).

\section{Selection of district}

In the first stage, Ghazipur district of eastern Utter Pradesh was selected purposively in order to avoid operational inconvenience of the respondent.

\section{Selection of block}

Out of 16 Blocks of Ghazipur district one block namely Bhanwarkola was selected purposively where tomato growers are in large numbers. 


\section{Selection of villages}

A list of the villages falling under selected block Bhanwarkola was prepared and five villages were selected randomly from the list.

\section{Selection of farmers}

A separate of tomato growers of selected villages was prepared along-with their size of holding and further it was grouped into three categories i.e.

1. Marginal farmer (<1 ha)

2. Small farmer (1-2 ha)

3. Medium farmer (2-4ha)

From this list 50 respondents were selected following the proportionate random sampling technique.

\section{Collection of data and method of enquiry}

\section{Primary data}

The data on production aspects were collected on well prepared schedule in advanced by survey method. Frequent visits were done by the investigator to the selected respondents and required data were recorded by personal interview. Accuracy of the data was assumed through cross-checking.

\section{Secondary data}

The secondary information was compiled from the published report at Block, Tehsil and District offices.

\section{Period of enquiry}

The data were collected to the main-season crop of the agriculture year 2016-2017.

\section{Analytical tools}

The data collected from the sample cultivators were analyzed and estimated with certain statistical techniques.

\section{Average}

The simplest and important measures of average which have been used into statistical analysis were the weighted average. The formula used to estimate the average is:

Weighted avergae $=\frac{\sum W_{i} X_{i}}{\Sigma W_{i}}$

Where,

$$
\begin{aligned}
\text { W. A. } & =\text { Weighted average } \\
X_{i} & =\text { Variable } \\
W_{i} & =\text { Weights of } X_{i}
\end{aligned}
$$

\section{Cost concepts}

The cost concepts and the items of cost included under this study are given below:

\section{Cost A1}

- This cost approximates and actual expenditure incurred in cash and kind.

- Values of hired/owned human, bullock and machinery and implements laborers Value of seed (both farm produced and purchased)

- Value of manure (owned and purchased)

- Value of insecticides and pesticides and chemical fertilizers

- Depreciation on implements and farm buildings

- Irrigation charges

- Land revenue, assets and other taxes

- Interest on working capital

- Miscellaneous expenses (artisans, etc.)

Cost A2: Cost A1 + rent paid for leased in land

Cost B1: Cost A2 + interest on value of owned fixed capital assets (Excluding land)

Cost B2: Cost B1 + rental value of owned land (net land revenue) and rent paid for leased in land.

Cost C1: Cost B1 + imputed value of family labour 
Cost C2: Cost B2 + imputed value of family labour

Cost C3: Cost $\mathrm{C} 2+10 \%$ of $\mathrm{C} 2$ (managerial cost).

Income concepts

\section{Gross income}

Value of farm output (main product and by product) whether sold or utilized by the farm family.

\section{Net income}

It is the difference between gross income and total cost, i.e. gross income minus cost $\mathrm{C} 1$ or Cost $\mathrm{C} 2$ or Cost $\mathrm{C} 3$.

\section{Family labour income}

Gross income minus cost B2.

\section{Farm business income}

Gross income minus cost A1 or cost A2 in case of land, leased in farm.

\section{Farm investment income}

Net income over cost $\mathrm{C} 2$ plus rental value of owned land plus

interest on owned fixed capital.

\section{Imputation procedures}

Some of the inputs used in the production process come from family sources. The procedures adopted for deriving imputed values are as given under:

\section{Family labour}

On the basis of wages paid to attached from servant.

\section{Owned animal labour}

On the basis of maintenance which includes the following:

Cost of green and dry fodder

Cost of concentrates

Depreciation on animals and cattle sheds

Labour charges

Other expenses, if any.

\section{Results and Discussion}

The result of the presents study as well as relevant discussion has been presented in cost and returns of tomato crop in the study area:

\section{Costs and returns}

The costs and returns have been summarized in this part on the sample farms. Beside the estimate of total costs, on the basis of six cost concept i.e. Cost $A_{1} / A_{2}$, cost $B_{1}$, cost $B_{2}$, cost $\mathrm{C}_{1}, \mathrm{C}_{2}$ and cost $\mathrm{C}_{3}$, have been worked out for estimation of cost. Similarly, the various measures of farm profits, such as net income, family labour income, farm investment income, farm business income, input-output ratio and resource use efficiency for tomato crop have also been worked out.

This section deals with the per hectare costs and returns of tomato crop on the sample farms. The costs and returns generated by tomato crop are displayed in Table 2 and 3.

\section{Per hectare costs of cultivation of tomato crop}

Per hectare costs incurred on the various input factor in the production of tomato was worked out and are given in Table 2.

Table 2 indicates that, costs of cultivation were highest on medium farms Rs.41318.40, followed by small farms Rs.39843.88 and marginal farms Rs. 38978.50 respectively. The overall average costs of cultivation were observed Rs. 39481.95 on sample farms. 
Table.1 Village wise proportionate selection of sample farmers under different size group of farms

\begin{tabular}{|c|c|c|c|c|c|c|c|c|c|}
\hline \multirow[t]{2}{*}{$\begin{array}{c}\text { Sl. } \\
\text { No. }\end{array}$} & \multirow{2}{*}{$\begin{array}{c}\text { Size of farms } \\
\text { Name of Villages }\end{array}$} & \multicolumn{2}{|c|}{$\begin{array}{c}\text { Marginal } \\
(<1 \text { ha. })\end{array}$} & \multicolumn{2}{|c|}{$\begin{array}{c}\text { Small } \\
\text { (1-2 ha.) }\end{array}$} & \multicolumn{2}{|c|}{$\begin{array}{l}\text { Medium } \\
\text { (2-4 ha.) }\end{array}$} & \multicolumn{2}{|c|}{ Total } \\
\hline & & $\mathrm{P}$ & $\mathrm{S}$ & $\mathrm{P}$ & $\mathrm{S}$ & $\mathrm{P}$ & $\mathrm{S}$ & $\mathrm{P}$ & $\mathrm{S}$ \\
\hline 1. & Pakhanpura & 88 & 6 & 46 & 3 & 20 & 1 & 154 & 10 \\
\hline 2. & Hadaria & 96 & 7 & 50 & 4 & 25 & 2 & 171 & 13 \\
\hline 3. & Bhawanrkola & 90 & 6 & 43 & 3 & 18 & 1 & 151 & 10 \\
\hline 4. & Firozpur & 74 & 5 & 35 & 2 & 20 & 1 & 129 & 8 \\
\hline \multirow[t]{2}{*}{5.} & Jasdevpur & 95 & 7 & 20 & 1 & 8 & 1 & 123 & 9 \\
\hline & Total & 443 & 31 & 194 & 13 & 91 & 6 & 728 & 50 \\
\hline
\end{tabular}

Note: $\mathrm{P}=$ Population and $\mathrm{S}=$ Sample

Table.2 Per hectare costs of different inputs used in tomato production (Rs.)

\begin{tabular}{|c|c|c|c|c|c|}
\hline \multirow[t]{2}{*}{ S.No } & \multirow[t]{2}{*}{ Particulars } & \multicolumn{4}{|c|}{ Size group of farms } \\
\hline & & Marginal & Small & Medium & Overall average \\
\hline 1. & Human Labour & $\begin{array}{c}14376.02 \\
(36.88)\end{array}$ & $\begin{array}{c}\text { 13813.06 } \\
(34.67)\end{array}$ & $\begin{array}{c}13853.24 \\
(33.52)\end{array}$ & $\begin{array}{c}14166.92 \\
(35.88)\end{array}$ \\
\hline a. & Family Labour & $\begin{array}{l}9751.19 \\
(25.02)\end{array}$ & $\begin{array}{c}3932.03 \\
(9.87)\end{array}$ & $\begin{array}{c}3303.16 \\
(7.99)\end{array}$ & $\begin{array}{c}7464.44 \\
(18.91)\end{array}$ \\
\hline b. & Hired Labour & $\begin{array}{c}4624.83 \\
(11.86)\end{array}$ & $\begin{array}{l}9881.03 \\
(24.80)\end{array}$ & $\begin{array}{c}10550.08 \\
(25.53)\end{array}$ & $\begin{array}{c}6702.47 \\
(16.97)\end{array}$ \\
\hline 2. & Machinery Charges & $\begin{array}{c}1051.00 \\
(2.69)\end{array}$ & $\begin{array}{l}1169.87 \\
(2.93)\end{array}$ & $\begin{array}{c}1199.98 \\
(2.90)\end{array}$ & $\begin{array}{c}1099.78 \\
(2.78)\end{array}$ \\
\hline 3. & Seed & $\begin{array}{c}1571.75 \\
(4.03)\end{array}$ & $\begin{array}{c}1815.21 \\
(4.55)\end{array}$ & $\begin{array}{c}2459.75 \\
(5.95)\end{array}$ & $\begin{array}{c}1741.61 \\
(4.41)\end{array}$ \\
\hline 4. & Manure and fertilizer & $\begin{array}{l}5082.53 \\
(13.04)\end{array}$ & $\begin{array}{l}5106.75 \\
(12.82)\end{array}$ & $\begin{array}{l}5382.50 \\
(13.02)\end{array}$ & $\begin{array}{l}5124.82 \\
(12.98)\end{array}$ \\
\hline 5. & Irrigation & $\begin{array}{c}3852.11 \\
(9.88)\end{array}$ & $\begin{array}{c}4284.28 \\
(10.75)\end{array}$ & $\begin{array}{c}4392.28 \\
(10.63)\end{array}$ & $\begin{array}{l}4029.29 \\
(10.20)\end{array}$ \\
\hline 6. & Plant Protection & $\begin{array}{c}2436.34 \\
(6.25)\end{array}$ & $\begin{array}{c}2663.62 \\
(6.68)\end{array}$ & $\begin{array}{c}2699.90 \\
(6.53)\end{array}$ & $\begin{array}{c}2527.06 \\
(6.40)\end{array}$ \\
\hline 7. & Total working capital & $\begin{array}{c}18618.56 \\
(47.77)\end{array}$ & $\begin{array}{c}24920.76 \\
(62.56)\end{array}$ & $\begin{array}{c}26683.59 \\
(64.58)\end{array}$ & $\begin{array}{c}21224.94 \\
(53.76)\end{array}$ \\
\hline 8. & $\begin{array}{l}\text { Interest on working } \\
\text { capital }\end{array}$ & $\begin{array}{r}744.74 \\
(1.91)\end{array}$ & $\begin{array}{c}996.83 \\
(2.50)\end{array}$ & $\begin{array}{c}1067.34 \\
(2.58)\end{array}$ & $\begin{array}{l}848.99 \\
(2.15)\end{array}$ \\
\hline 9. & Rental value of land & $\begin{array}{l}6000.00 \\
(15.39)\end{array}$ & $\begin{array}{l}6000.00 \\
(15.06)\end{array}$ & $\begin{array}{l}6000.00 \\
(14.52)\end{array}$ & $\begin{array}{c}6000.00 \\
(15.19)\end{array}$ \\
\hline 10. & $\begin{array}{l}\text { Interest on fixed } \\
\text { capital }\end{array}$ & $\begin{array}{l}320.26 \\
(0.82)\end{array}$ & $\begin{array}{l}363.91 \\
(0.91)\end{array}$ & $\begin{array}{l}508.09 \\
(1.22)\end{array}$ & $\begin{array}{l}354.15 \\
(0.89)\end{array}$ \\
\hline 11. & Sub total & $\begin{array}{c}35434.75 \\
(90.91)\end{array}$ & $\begin{array}{c}36213.53 \\
(90.91)\end{array}$ & $\begin{array}{c}37562.18 \\
(90.91)\end{array}$ & $\begin{array}{c}35892.52 \\
(90.91)\end{array}$ \\
\hline 12. & $\begin{array}{l}\text { Managerial Cost } \\
@ 10 \% \text { of sub-total }\end{array}$ & $\begin{array}{c}3543.47 \\
(9.09)\end{array}$ & $\begin{array}{l}3621.35 \\
(9.09)\end{array}$ & $\begin{array}{c}3756.22 \\
(9.09)\end{array}$ & $\begin{array}{c}3589.25 \\
(9.09)\end{array}$ \\
\hline & Grand total & $\begin{array}{c}38978.50 \\
(100)\end{array}$ & $\begin{array}{l}39834.88 \\
(100)\end{array}$ & $\begin{array}{l}\text { 41318.40 } \\
(100)\end{array}$ & $\begin{array}{c}39481.95 \\
(-100)\end{array}$ \\
\hline
\end{tabular}

Figure in parenthesis indicate percentage to the total cost 
Table.3 Per hectare costs and returns from the production of tomato crop on various costs concept (Rs.)

\begin{tabular}{|c|c|c|c|c|c|}
\hline \multirow[t]{2}{*}{ S.No } & \multirow{2}{*}{ Particulars } & \multicolumn{4}{|c|}{ Size group of farms } \\
\hline & & Marginal & Small & Medium & Overall average \\
\hline 1. & Cost A1/A2 & 19363.30 & 25917.59 & 27750.93 & 22073.93 \\
\hline 2. & Cost B1 & 19683.56 & 26281.50 & 28259.02 & 22428.08 \\
\hline 3. & Cost B2 & 25683.56 & 32281.50 & 34259.02 & 28428.08 \\
\hline 4. & Cost $\mathrm{C} 1$ & 29434.75 & 30213.53 & 31562.18 & 29892.52 \\
\hline 5. & Cost $\mathrm{C} 2$ & 35434.75 & 36213.53 & 37562.18 & 35892.52 \\
\hline 6. & Cost C3 & 38978.50 & 39834.88 & 41318.40 & 39481.95 \\
\hline 7. & Yield q/ha. & 158.88 & 157.43 & 156.80 & 158.25 \\
\hline 8. & Grass Income & 79440.00 & 78715.00 & 78400.00 & 79126.70 \\
\hline 9. & Net return over cost $C 3$ & 40461.50 & 38880.12 & 37081.60 & 39644.75 \\
\hline 10. & Family Income & 53756.44 & 46433.50 & 44140.98 & 50698.62 \\
\hline 11. & Farm Business income & 60076.70 & 52797.41 & 50649.07 & 57052.77 \\
\hline 12. & Farm investment income & 50325.51 & 48865.32 & 41345.91 & 49588.33 \\
\hline 13. & $\begin{array}{l}\text { Cost of production } \\
\text { (Rs./qtl) }\end{array}$ & 254.66 & 246.96 & 236.49 & 250.52 \\
\hline 14. & Input-Output ratio & & & & \\
\hline a. & On the basis of cost A1 & $1: 4.10$ & $1: 3.04$ & $1: 2.83$ & $1: 3.58$ \\
\hline b. & On the basis of cost $\mathrm{B} 1$ & $1: 4.03$ & $1: 2.99$ & $1: 2.77$ & $1: 3.53$ \\
\hline c. & On the basis of cost $B 2$ & $1: 3.09$ & $1: 2.44$ & $1: 2.29$ & $1: 2.78$ \\
\hline d. & On the basis of cost $\mathrm{C} 1$ & $1: 2.69$ & $1: 2.60$ & $1: 2.48$ & $1: 2.65$ \\
\hline e. & On the basis of cost $\mathrm{C} 2$ & $1: 2.24$ & $1: 2.17$ & $1: 2.09$ & $1: 2.20$ \\
\hline f. & On the basis of cost $\mathrm{C} 3$ & $1: 2.03$ & $1: 1.98$ & $1: 1.90$ & $1: 2.00$ \\
\hline
\end{tabular}

The major component of the cost were human labour 35.88 per cent, rental value of owned land 15.19 per cent, manure and fertilizers 12.98 per cent, irrigation charge 10.20 per cent, plant protection 6.40 per cent, seed 4.41 per cent, machinery charge 2.78 per cent respectively of the total average costs of cultivation.

Per hectare costs and return from the production of tomato crop

The Table 3 revealed that, on an average cost $\mathrm{A}_{1} / \mathrm{A}_{2}, \cos \mathrm{t} \mathrm{B}_{1}, \cos \mathrm{B}_{2}, \cos t \mathrm{C}_{1}, \operatorname{cost} \mathrm{C}_{2}$ and cost $\mathrm{C}_{3}$ came to Rs.22073.93, Rs.22428.08, Rs. 28428.08, Rs. 29892.52, Rs.35892.52 and Rs. 39481.95, respectively.
On an average, gross income was recorded Rs. 79126.70 and net income came to Rs.39644.75. On marginal farms, gross income was highest, which was recorded Rs.79440.00, followed by small farms Rs. 78715.00 and lowest on medium farms i.e. Rs.78400.00 respectively.

The net income was highest on marginal farms Rs. 40461.50, followed by small farms Rs. 38880.12 and medium farms Rs. 37081.60. On an average family labour income, farm business income and farm investment income were observed to Rs. 50698.62, Rs. 57052.77 and Rs. 49588.33, respectively. 
Family labour income was highest on marginal farms followed by small and medium farms and farm investment income was highest on marginal farms followed by small farm and medium farms and farm business income was highest on marginal farms, followed by small farms and medium farms. On an average, cost of production per quintal and yield per hectare were estimated to Rs. 250.52 per quintal and 158.25 quintal respectively.

On an average input output ratio regarding costs $\mathrm{C}_{3}, \mathrm{C}_{2}, \mathrm{C}_{1}, \mathrm{~B}_{2}, \mathrm{~B}_{1}$, and $\mathrm{A}_{2} / \mathrm{A}_{1}$ were recorded 1:2.00, 1:2.20, 1:2.65, 1:2.78, 1:3.53 and 1:3.58 respectively. On the basis of cost $\mathrm{C}_{3}$ input output ratio was highest on marginal farms (1:2.03), followed by small (1:1.98) and medium (1:1.90) respectively.

\section{References}

Khemnar, S. H.; Navadkar, D. S. and Dangat, S. B. (1994). Profitability of Tomato cultivation in Ahamadnagar district of Maharashtra State. Indian Journal of Agriculture Marketing. Vol. 8(1):96-
100.

Kiresur, V.R. and Hiremath, K.C. (1993). Cost returns profit in vegetable production. A case study in Dharwad district of Karnataka. J. of Agric. Sci., 6 (1): 74-76.

Navadhar, D. S.: Dorge, J. T. and Yadav, D. D. (2003). Effects of growing season on productivity and profitability of tomato in Western in Maharashtra, Indian J. of Agril. Marketing. 17(2);111-115.

Pan, R. S. Suresh Kumar Govind Pal Singh, A. K. Tirkey, I. (2011). Economics and resource efficiency of tomato (Solanum lycopersicum) cultivation in Jharkhand. Banaras Hindu University - CAB Abstracts New Agriculturist; 2011. 22(2):185-192. 14 ref.

Singh, M. K. (2005). Economic analysis of production and marketing of vegetables in Madhya Pradesh, India. International Journal of Rural Studies. 12 (2): $11-23$.

\section{How to cite this article:}

Punam Kushwaha, Harendra Pratap Singh Chaudhri, R.R. Verma and Kushwaha, R.R. 2018. Cost and Income Analysis of Tomato cultivation in Ghazipur District of Uttar Pradesh, India. Int.J.Curr.Microbiol.App.Sci. 7(07): 1566-1572. doi: https://doi.org/10.20546/ijcmas.2018.707.185 